\title{
POWSTANIE, ROZWÓJ I KRYZYS KONCEPCJI WÓJTA (BURMISTRZA, PREZYDENTA MIASTA) JAKO LOKALNEGO PRZYWÓDCY
}

Michał Kasiński*

\author{
THE EMERGENCE, DEVELOPMENT, \\ AND CRISIS OF CONCEPT OF THE VOIT, MAYOR, \\ AND CITY PRESIDENT AS A LOCAL LEADER
}

\begin{abstract}
Presented study concentrates on both forming and the crisis of the concept of local leadership in Poland, which concerns voits, mayors, and presidents of cities, directly elected by the citizens - e.g. a local government leaders. Particular attention was paid to legal and political mechanisms of their elections and political (democratic) responsibility towards the citizens. In these mechanisms, the factors were detected, which substantially weaken social trustworthiness of the role of the leader. Among them: particularly low rate of voting turnout in both local elections and referenda concerning deposition from appointments listed above and various manipulations distorting the true picture of public in these matters. Concept of a local leader in Poland has met very serious difficulties in practice and seems to be not attractive to the community.
\end{abstract}

- KEYWORDS

leadership, local government, elections, political (democratic) responsibility

* Uniwersytet Łódzki, Wydział Prawa i Administracji. 


\section{WPROWADZENIE}

Idea lokalnego przywództwa znajduje we współczesnym świecie licznych zwolenników. W wielu krajach przeprowadzane są inspirowane tą ideą reformy ustroju władz lokalnych ${ }^{1}$. W niniejszym studium podejmuję próbę określenia wpływu, jaki idea lokalnego przywództwa wywierała i nadal wywiera na przemiany prawnoustrojowej regulacji mechanizmu władzy w polskiej samorządowej gminie. Rozważam także sprawę następstw wdrażania koncepcji lokalnego przywódcy dla losów demokracji lokalnej na tym szczeblu.

Przywództwo lokalne to jeden z rodzajów przywództwa politycznego, pojmowanego jako szczególna umiejętność, typ relacji bądź też jako proces społeczny². Nie budzi wątpliwości teza, że jak każde przywództwo polityczne oznacza trwałe i przewidywalne wpływanie na zachowania ludzi w sferze polityki, w tym przypadku polityki lokalnej. Dyskusyjne są jednak podmiotowy zakres tego wpływu oraz jego siła sprawcza ${ }^{3}$. Szczególnie cenne dla naszych rozważań jest stanowisko Andrzeja Antoszewskiego, który zwraca uwagę na konsekwencje dokonującej się w państwach pokomunistycznych instytucjonalizacji przywództwa - jego włączenia do struktur władzy państwowej i wyposażenia przywódcy w możliwości korzystania z uprawnień posługiwania się aparatem przymusu, czyli przekształcenia przywództwa rozumianego jako fakt psychosocjologiczny we władzę państwową (instytucję polityczną) $)^{4}$ Proces ten występuje także w terenowych strukturach władzy publicznej i prowadzi do zatarcia granicy między przywódcami lokalnymi a piastunami organów samorządowych.

Dodatkowo warto zwrócić uwagę na dwie kwestie: 1) Rola przywódcy lokalnego ma niewątpliwe aspekty polityczne, związane $\mathrm{z}$ uczestniczeniem

1 Transforming Local Political Leadership, red. R. Berg, N. Rao, New York 2005; C. Copus, Leading the Localities. Executive Mayors in English Local Governance, Manchester-New York 2006; Local Government in Central and Eastern Europe. The Rebirth of Local Democracy, red. A. Coulson, A. Campbell, London-New York 2008; P. Delwitt, J.B. Pilet, H. Reyaert, K. Steyvers, Local Political Leadership in Europe. Town Chief, City Boss or Loco President?, Brugge 2009.

2 P. Żukiewicz, Przywództwo polityczne. Teoria i praktyka, Warszawa 2011, s. 47-48, 69-73, 296 i n.

3 J. Wiatr, Przywództwo polityczne. Studium politologiczne, Łódź 2008, s. 23; J. Sielski, Przywódcy i liderzy samorządowi (lokalni). Teoretyczne ujęcie przywództwa politycznego. Studium przypadku Polska, [w:] Kryzys przywództwa we współczesnej polityce, red. W. Konarski, A. Durska, S. Bachrynowski, Warszawa 2011, s. 147.

4 A. Antoszewski, Instytucjonalizacja przywództwa politycznego w państwach postkomunistycznych, [w:] Przywództwo polityczne. Teorie i rzeczywistość, red. L. Rubisz, K. Zuba, Toruń 2004, s. 38. 
w sprawowaniu władzy publicznej w gminie. Ale rola ta ma także istotne aspekty pozapolityczne, związane z zarządzaniem gminą, merytorycznym wpływem na funkcjonowanie społeczności i rozwiązywaniem konkretnych problemów życia zbiorowego. 2) Powinna to być rola przywódcy demokratycznego, gdyż konstytucyjny ustrój polskiej gminy oparty został na zasadach demokracji i pluralizmu. Przywództwo lokalne powinno być równocześnie przywództwem służebnym i odpowiedzialnym wobec lokalnej społeczności5. Przywódca lokalny jest osobą, która dzięki posiadanym cechom i umiejętnościom jest w stanie skłonić pozostałych członków społeczności do podjęcia działań zmierzających do realizacji określonych przez siebie lub samą społeczność celów. Jego władza zawsze opiera się na akceptacji i zaufaniu mieszkańców i trwa, dopóki owa akceptacja i kredyt zaufania nie zostaną utracone ${ }^{6}$. Przywódcza rola osoby „obdarzonej” władzą przez społeczność lokalną, to znaczy demokratycznie wybraną, trwa, dopóki osoba ta zachowuje społeczną wiarygodność. Może ją utracić na przykład w rezultacie nieskuteczności swoich działań, doprowadzenia do dezintegracji społeczności lokalnej czy też sprzeniewierzenia się ważnym dla niej ideałom i wartościom. W systemie demokratycznym żaden przywódca nie może uchylić się od odpowiedzialności przed społecznością za prawidłowe wypełnianie swojej roli.W przeciwnym razie jego władza nie ma charakteru przywództwa, lecz jest dyktatorskim władaniem nad pozostałymi członkami społeczności. Przywództwo może być określone jako umiejętność mobilizowania obywateli do wspólnych działań poprzez wyznaczenie im celu i skłonienie do uznania go za cel własny?

W przypadku przywódcy samorządowej gminy, w której pierwotnym podmiotem władzy są mieszkańcy (wspólnota samorządowa), jego cele reprezentować powinny wartości i motywacje wyrażone prawnie oraz akceptowane na zasadach demokratycznych przez społeczność lokalną, a nie tylko jego samego czy bezpośrednich zwolenników. Istotne są także relacje zwrotne odpowiedzialność ${ }^{8}$ za realizację owych wspólnych celów i wartości, dokonująca się nie tylko przed zwolennikami, ale całą społecznością. Kryterium i miarą

${ }^{5}$ Por. A. Augustyn, Przywództwo liderów lokalnych w zarządzaniu jednostką samorządu terytorialnego, [w:] Przedsiębiorczość szansq̨ rozwoju regionu, „Zeszyty Naukowe Uniwersytetu Szczecińskiego. Ekonomiczne problemy usług” 2012, 274, nr 97, s. 15-16.

6 P. Sztompka, Socjologia, Warszawa 2007, s. 381-383, 385.

7 A. Pawłowska, Prawno-instytucjonalny wymiar przywództwa lokalnego (na przykładzie wybranych państw), [w:] Model przywództwa, red. A.K. Piasecki, Kraków 2006, s. 442.

8 M. Bovens, T. Schillemens, R.E. Goodin, Public Accountability, [w:] The Oxford Handbook Accountability, red. eaedem, Oxford 2014. 
wiarygodności przywódcy w oczach obywateli jest pozytywny wynik testu jego odpowiedzialności (demokratycznej ${ }^{9}$ ) przed mieszkańcami gminy lub/oraz ich przedstawicielstwem, przeprowadzanego na zasadach demokratycznych.

\section{GENEZA KONCEPCJI LOKALNEGO PRZYWÓDZTWA W GMINIE}

Reforma z 1990 roku miała na celu demokratyzację i decentralizację władzy lokalnej poprzez odrzucenie zasady jednolitej władzy państwowej i przywrócenie samorządności gmin. W pierwszym okresie po uchwaleniu ustawy z 8 marca 1990 roku o samorządzie terytorialnym (obecnie ustawa o samorządzie gminnym) nie zwracano uwagi na kwestie lokalnego przywództwa. Największe znaczenie przypisywano legitymizacji samorządowego przedstawicielstwa - rady gminy, określonej w ustawie jako organ stanowiący i kontrolny. W pierwszych wyborach do rad gmin (27 maja 1990 roku) odnotowano wprawdzie niską frekwencję $42,27 \%$ uprawnionych do głosowania, sukces jednak miał miejsce. Polegał on nie tyle na zwycięstwie komitetów obywatelskich (ich kandydaci uzyskali około 50\% mandatów), co przede wszystkim na kwalifikacjach społecznych nowych radnych i uzyskaniu wysokiego stopnia reprezentatywności. Podstawą tego sukcesu była liberalna ordynacja wyborcza, która stworzyła szerokie możliwości zgłaszania kandydatów na radnych, nie przyznając preferencji partiom politycznym ${ }^{10}$. W świadomości obywateli powstało przekonanie, że mogą decydować o składzie najważniejszego organu władzy lokalnej - rady gminy. Władza uzyskała warunki swej demokratycznej legitymizacji i społecznej akceptacji1 ${ }^{11}$.

W początkowym okresie działania samorządu gminnego akcentowana była przede wszystkim doniosłość budowy podstaw demokracji lokalnej i społeczeństwa obywatelskiego, skuteczności działania rady gminy, jej nadrzędnej roli wobec organu wykonawczego (zarządu gminy) oraz realności mechanizmów odpowiedzialności demokratycznej na tym szczeblu ${ }^{12}$. Wkrótce jednak proces decentralizacji został zatrzymany. Władzom lokalnym nie zapewniono stabilnych

9 M. Kasiński, Monizm i pluralizm władzy lokalnej. Studium prawno-polityczne, Łódź 2009, s. $405-458$.

10 S. Wójcik, Samorząd terytorialny w Polsce w XX wieku. Myśl samorządowa - historia i wspótczesność, Lublin 1999, s. 277.

${ }^{11}$ A. Piekara, Samorząd terytorialny i inne formy aktywności społecznej dawniej i dzisiaj, Warszawa 2005, s. 147-148.

12 Zob. M. Kasiński, Monizm i pluralizm, op.cit., s. 465-476. 
i wystarczająco wydajnych źródeł dochodów oraz gwarancji samodzielności dokonywania wydatków budżetowych i gospodarowania mieniem komunalnym. W warunkach kryzysu gospodarczego i społecznego słabła efektywność nowych władz, słabł ich autorytet społeczny. Szczególnie dotkliwie odczuwane były negatywne skutki łatwej destabilizacji organów wykonawczych, nader częstych zmian na stanowiskach wójtów, burmistrzów i prezydentów miast. Po zakończeniu działalności komitetów obywatelskich (tj. po wyborach parlamentarnych we wrześniu 1991 roku) w radach gmin, szczególnie w większych miastach, coraz silniejsze stawały się wpływy partii politycznych. Towarzyszył temu wyraźny spadek zainteresowania wyborami samorządowymi. W wyborach do rad gmin II kadencji frekwencja w skali ogólnopolskiej nie osiągnęła nawet 40\%. Nowa ordynacja wyborcza z 1998 roku przewidywała, że wybory do rad gmin w gminach powyżej 20 tysięcy mieszkańców (a nie jak poprzednio w gminach powyżej 40 tysięcy mieszkańców) mają odbywać się na zasadzie proporcjonalności, co oznaczało wzmocnienie preferencji dla kandydatów z list partii ogólnopolskich. Ten sam efekt przyniosły zmiany ordynacji wprowadzające metodę d'Hondta przy podziale mandatów dla poszczególnych list. Nadmierne upartyjnienie składu rad gmin spowodowało dalsze rozluźnienie więzi między radnymi i wyborcami w toku kadencji. Wójt i zarząd gminy w swej działalności byli coraz silniej uzależnieni od zmieniających się układów polityczno-personalnych w radzie, nieustannie musieli prowadzić negocjacje z różnymi grupami radnych.

W środowiskach działaczy lokalnych taki stan rzeczy musiał budzić sprzeciw i poszukiwanie środków zaradczych. $Z$ biegiem lat coraz silniej akcentowano potrzebę zagwarantowania stałości składu organu wykonawczego gminy i ochrony jego samodzielności wobec rady. Narastał skuteczny nacisk na wprowadzenie zmian prawnych umacniających pozycję szefa organu wykonawczego oraz ograniczających nadrzędną rolę rady gminy. Ewolucja regulacji prawnej coraz bardziej oddalała ustawę o s.t. od modelu opisanego w art. 3 ust. 2 Europejskiej Karty Samorządu Lokalnego, zgodnie z którym rada powinna dysponować organem wykonawczym jej podlegającym ${ }^{13}$. Według pierwotnego tekstu ustawy o samorządzie terytorialnym zarząd gminy wybierała rada gminy w głosowaniu tajnym w zasadzie spośród radnych. Jedynie wójt (burmistrz, prezydent miasta) i jego zastępcy mogli być wybierani także spoza składu rady. Tylko zastępcy wójta dotyczył wymóg zgłoszenia kandydata przez wójta. W 1995 roku wprowa-

13 Komentarz do ustawy o samorządzie gminnym, red. P. Chmielnicki [et. al.], Warszawa 2007, s. 297. 
dzono koncepcję tzw. zarządu autorskiego. Odtąd cały skład zarządu gminy rada mogła wybierać spośród radnych lub spoza rady; wójta wybierała bezwzględną większością głosów ustawowego składu rady, a następnie - wyłącznie na jego wniosek - pozostałych członków zarządu zwykłą większością głosów, w obecności co najmniej połowy ustawowego składu rady. W kolejnych nowelizacjach utrudniono procedurę odwoływania wójta oraz ograniczono dopuszczalną liczbę członków zarządu gminy.

Kierunek przeprowadzanych zmian odpowiadał wielu urzędnikom samorządowym, ale i lokalnym liderom partyjnym, zainteresowanym umacnianiem pozycji i usamodzielnianiem organów wykonawczych. W latach dziewięćdziesiątych ukształtowane zostało „samorządowe lobby”, zdominowane przez etatowych polityków samorządowców, którzy różnymi kanałami wpływu, przede wszystkim poprzez stowarzyszenia samorządowe i niektóre partie polityczne, wywierali nacisk na emancypację prawnoustrojową organu wykonawczego gminy. W tym środowisku pojawił się i coraz częściej przedstawiany był w debacie publicznej postulat zadekretowania pozycji wójta, jako bezpośrednio wybieranego przez mieszkańców organu, zdolnego do wypełniania roli lokalnego przywódcy. Najwcześniej i najsilniej koncepcje takie były prezentowane przez ogólnopolskie stowarzyszenia samorządowe, zwłaszcza Związek Miast Polskich. Partie polityczne podchodziły do tej sprawy raczej koniunkturalnie. Sytuacja uległa radykalnej zmianie w 2001 roku, gdy z programami reformy ustroju gmin wystąpiły duże partie ogólnopolskie oraz organizacje samorządowe. Platforma Obywatelska (PO) postulowała wprowadzenie zasady wybierania przez mieszkańców wszystkich gmin jednoosobowych organów wykonawczych, przyznanie wójtom kompetencji do powoływania i odwoływania swoich zastępców oraz istotne rozszerzenie kompetencji do bieżącego zarządzania w sprawach finansowych i majątkowych. Podobne stanowisko zajęły Związek Miast Polskich oraz Związek Gmin Wiejskich. Sojusz Lewicy Demokratycznej (SLD) proponował bezpośrednie wybory organów wykonawczych jedynie w gminach do 20 tysięcy mieszkańców oraz utrzymanie ich kolegialnego charakteru. Przeciw koncepcji bezpośrednich wyborów wójtów, burmistrzów i prezydentów miast wypowiedziało się natomiast Prawo i Sprawiedliwość (PiS), argumentując, że takie rozwiązanie zwiększa zagrożenie korupcją i prowadzi do innych patologii władzy niekontrolowanej ${ }^{14}$.

${ }^{14} \mathrm{~K}$. Marszał, Wpływ bezpośredniego wyboru wójta, burmistrza i prezydenta miasta na lokalny system polityczny, http://www.otnostrow.org.pl//pliki/rocznik 2006/07 marszal.pdf, s. 3 i n., odczyt 
Rok później koalicja parlamentarna SLD-PSL zrealizowała niektóre postulaty PO i organizacji samorządowych. Na mocy Ustawy z dnia 20 czerwca 2002 roku o bezpośrednim wyborze wójta, burmistrza, prezydenta miasta usunięto wybierany przez radę gminy kolegialny zarząd, wprowadzając w jego miejsce wybieranego przez mieszkańców wójta, który nie może być równocześnie radnym tej samej gminy. W ten sposób pierwotne cechy modelu organu wykonawczego gminy zostały odwrócone. Odrzucenie zasady wybieralności tego organu przez radę i pozbawienie jej w praktyce skutecznych narzędzi egzekwowania swoich uchwał postawiły pod znakiem zapytania samo istnienie jego podległości wobec samorządowego przedstawicielstwa. Otworzyły natomiast na nowo dyskusję na temat współczesnego sensu demokracji lokalnej.

\section{KSZTAŁTOWANIE ROLI ORGANU WYKONAWCZEGO GMINY JAKO PRZYWÓDCY LOKALNEGO W ŚWIETLE PRAWA I PRAKTYKI POLITYCZNEJ W LATACH 2002-2014}

Pojawienie się na samorządowej scenie politycznej postaci określanych mianem lokalnych przywódców łączone jest najczęściej z ustanowieniem w 2002 roku jednoosobowych organów wykonawczych gminy, wybieranych przez uprawnionych mieszkańców w wyborach powszechnych i bezpośrednich. Niekiedy widzi się w tym ukoronowanie wieloletniego procesu cząstkowych reform gminnego samorządu, których wspólnym motywem i strategicznym celem było ustanowienie takiego niezależnego od rady organu gminy, demokratycznie wybranego lokalnego lidera politycznego ${ }^{15}$ - jakkolwiek sugerowałbym ostrożność w odniesieniu do takich opinii. Koncepcja lokalnego przywództwa stanowiła pewne wsparcie ideologiczne dla słabnącego autorytetu społecznego nieudolnie reformowanej władzy lokalnej. W rzeczywistości bezpośrednie wybory wójtów, burmistrzów i prezydentów miast $\mathrm{t}^{16}$ miały przede wszystkim zapewnić dominującą pozycję w gminach partiom i ich lokalnym liderom. Mieli oni być legitymowani demokratycznie jako lokalni przywódcy polityczni i równocześnie menedżerowie potrafiący sprawnie zarządzać gminami. W praktyce ten drugi

\footnotetext{
$\mathrm{z}$ dn. 8.02.2015.

15 J. Kowalik, Wójt, burmistrz, prezydent miasta - między politykiem a menedżerem, [w:] Kryzys przywództwa, op.cit., s. 345.

${ }^{16}$ W dalszej części opracowania wykorzystany zostanie skrót - zamiast rozwiniętej formy wójt, burmistrz, prezydent miasta wykorzystywana będzie forma wójt.
} 
rezultat w wielu gminach nie wystąpił, zresztą zapewne nie był możliwy do osiągnięcia przez samą zmianę trybu obsady tych stanowisk. Organ wykonawczy nie uzyskał nowych uprawnień, umożliwiających względnie samodzielne zarządzanie gminą, dopiero kilka lat później jego kompetencje w tym zakresie uległy pewnemu rozszerzeniu. W 2002 roku wprowadzono natomiast konfliktowy model relacji między wójtem a radą gminy. Opozycyjnie nastawiona większość radnych może odtąd skutecznie paraliżować projekty zgłaszane przez wójta, ten zaś może skutecznie torpedować wykonanie podjętych wbrew jego woli uchwał rady, jako że rada pozbawiona została kompetencji do odwołania wójta, może jedynie inicjować przeprowadzenie referendum w tej sprawie.

Początkowo reforma spotkała się z pozytywnym odbiorem społecznym, rozbudziła nadzieje wielu mieszkańców na realny wybór osoby zdolnej do skutecznego rozwiązywania problemów lokalnych, oraz nastąpi „odpartyjnienie” władzy gminnej. Rozczarowanie przyszło szybko. W samorządowej kampanii wyborczej w 2002 roku partie toczyły otwartą „bitwę o teren”, zakończoną wprowadzeniem do rad oraz na stanowiska organów wykonawczych gmin wielu działaczy partyjnych ${ }^{17}$. Wyniki pierwszych bezpośrednich wyborów wójta mogły wywołać przygnębiające wrażenie, przede wszystkim z powodu niskiej frekwencji: w pierwszej turze wyborów 44,23\%, w drugiej turze - 35,2\% uprawnionych. Bezwzględną większością głosów wybrano nieco więcej niż połowę piastunów organów wykonawczych gmin, i to prawie wyłącznie wójtów i burmistrzów w małych gminach. W niektórych dużych miastach frekwencja nie przekroczyła 20\%. Trudno czuć się przywódcą lokalnym, jeśli zostało się burmistrzem lub prezydentem miasta dopiero po „dogrywce” w drugiej turze wyborów, a w obydwu turach wzięła udział jedynie niewielka liczba uprawnionych. W kolejnych kadencjach pod tym względem sytuacja niewiele się zmieniła. Decyzja udziału w wyborach samorządowych dotychczas podejmowana była w skali kraju tylko przez mniejszość uprawnionych obywateli, a frekwencja wyborcza w miastach była $\mathrm{z}$ reguły niższa niż w gminach wiejskich. W wyborach z 2014 roku uczestniczyło w pierwszej turze 47,40\%, a w drugiej turze 39,90\% uprawnionych do głosowania ${ }^{18}$. Frekwencja w pierwszej turze była zbliżona do uzyskanej w poprzedniej kadencji i tylko o 5\% wyższa niż w pierwszych wybo-

\footnotetext{
17 S. Michałowski, op.cit., s. 38-39.

18 Obwieszczenie Państwowej Komisji Wyborczej z dnia 23 listopada 2014 r. o zbiorczych wynikach wyborów wójtów, burmistrzów i prezydentów miast na obszarze kraju przeprowadzonych $w$ dniu 16 listopada 2014 r., „Dziennik Ustaw” 2014, poz. 1642; Obwieszczenie Państwowej Komisji Wyborczej z dnia 1 grudnia 2014 r. uzupetniajace obwieszczenie $z$ dnia 23 listopada 2014 r. o zbiorczych wynikach
} 
rach do rad gmin z 1990 roku. Po ćwierćwieczu istnienia samorządu gminnego trudno to uznać za sukces.

W kadencjach 2006-2010 oraz 2010-2014 dominacja partii w strukturach władzy gminnej w pewnym stopniu osłabła, większość stanowisk obsadzili kandydaci podający się za niezależnych. W wyborach z 2014 roku największe partie uzyskały tylko nieco ponad 18\% mandatów wójtów, burmistrzów i prezydentów miast. Resztę zdobyli kandydaci mniejszych ugrupowań politycznych, organizacji pozarządowych i tworzonych ad hoc komitetów wyborców. Utrwaliła się natomiast silna tendencja reelekcji tych samych osób na kolejne kadencje. Według niektórych analiz w 1130 gminach $(45,7 \%)$ władzę wykonawczą sprawują te same osoby co najmniej od 2002 roku $^{19}$.

Skala reelekcji może budzić niepokój. W 2014 roku spośród 64 prezydentów miast na prawach powiatu tylko 21 zostało wybranych po raz pierwszy, $43(67,2 \%)$ na kolejną kadencję, w tym 28 prezydentów miast (około 45\%) będzie pełnić swój urząd już w trzeciej, czwartej, piątej, a w jednym przypadku nawet w siódmej kadencji. Nieco ponad połowa (36) wskazanych polityków kandydowała $\mathrm{z}$ komitetów wyborczych wyborców, 28 było zgłoszonych przez partie. W grupie tych, którzy wybrani zostali po raz drugi, jest 4 kandydatów niezależnych, a 11 zgłoszonych przez partie. Natomiast w grupie 28 prezydentów wybranych po raz trzeci lub więcej razy tylko 7 zostało zarejestrowanych przez partie polityczne. Wszelako 5 innych, mimo że wystąpiło z ramienia komitetów wyborczych wyborców, deklarowało jednocześnie członkostwo w partii. W jednym przypadku miała miejsce jawna koalicja bezpartyjnego kandydata z partią (KWW Rafał Dudkiewicz z PO we Wrocławiu) ${ }^{20}$.

Wybór kandydatów niezależnych oraz ich reelekcja mogą być w wielu przypadkach rezultatami społecznej reakcji na narastającą w latach dziewięćdziesiątych i na początku XXI wieku „lokalną partiokrację”, coraz silniej wyrażanego w społeczeństwie przekonania, że kandydaci partyjni nie reprezentują interesów mieszkańców. Z drugiej strony bezpartyjność lub „ponadpartyjność” kandydatów ubiegających się o wybór i reelekcję bywają tylko taktycznymi wybiegami: identyfikacja z partią nie jest atutem w oczach wyborców, toteż szansa na zwycięstwo

wyborów wójtów, burmistrzów i prezydentów miast na obszarze kraju, „Dziennik Ustaw” 2014, poz. 1700.

19 S. Bartnicki na seminarium Ośrodka Analiz Politologicznych UW w dniu 14.11.2014 r.: Lokalni politycy i lokalni wyborcy u progu ciszy wyborczej, http://oapuw.pl, odczyt z dn. 8.02.2015.

20 Obliczenia własne na podstawie http://wybory 2014.pkw.pl/pl/wyniki/województwa/, odczyt $\mathrm{z}$ dn. 5.12.2014. Wyborów prezydenta miasta nie przeprowadzono w 2014 r. w Zielonej Górze. 
wyborcze skłania do przynajmniej pozornego usamodzielnienia się wobec partii. W rzeczywistości największe ogólnopolskie partie w średnich i dużych miastach zachowały istotne wpływy. Spadek społecznej wiarygodności partyjnych działaczy samorządowych skłonił natomiast partie polityczne do transformacji swego wpływu na władzę lokalną, w tym także do stosowania przez ich kandydatów taktyki kamuflażu, występowania pod szyldem niezależności. W tych warunkach mit wolnego od układów partyjnych burmistrza lub prezydenta miasta niewiele ma wspólnego z rzeczywistością.

Są i sytuacje odmienne - gdy prezydent miasta, który początkowo związany był z partią, w toku kadencji uwalnia się od tej zależności i wykorzystując pozycję, buduje własne zaplecze polityczne, aby w następnych wyborach kandydować już z własnego, niezależnego komitetu wyborczego. Taka osoba niewątpliwie może być uznana za przywódcę grupy swoich zwolenników, co jednak nie jest tożsame z pełnieniem roli lokalnego przywódcy w znaczeniu przyjętym w niniejszym opracowaniu. Urzędujący prezydent, mając dostęp do najważniejszych zasobów miasta, $\mathrm{z}$ reguły jest faworytem wyborów. W szczególności jest największym lokalnym pracodawcą i sprawuje kontrolę nad najważniejszymi instytucjami w mieście, co łatwo wytwarza tzw. układ. Wobec kogoś takiego trudno zbudować skuteczną opozycję. Reelekcja jest gwarancją stabilizacji tego układu - zainteresowanych jest nią bardzo wiele osób, dla których zmiana na stanowisku prezydenta może stanowić zagrożenie. Okazuje się, że sukcesy wyborcze prezydentów wynikają nie tylko z predyspozycji menedżerskich, doświadczenia samorządowego, ożywienia inwestycyjnego i gospodarczego w miastach, ale także $\mathrm{z}$ umiejętnego marketingu i public relations, przyzwyczajenia elektoratu, zręcznego eliminowania (tzn. zniechęcania) poważniejszych kontrkandydatów, a wreszcie z deklarowanej niezależności ${ }^{21}$.

W mniejszych miastach i gminach wiejskich również wystąpił proces „lokalizacji polityki lokalnej”. Kandydaci lokalnych komitetów wyborców już w kadencji 2002-2006 wygrywali wybory w gminach, w których poprzednio władzę sprawowali przedstawiciele partii politycznych. W licznych gminach w kolejnych wyborach zwyciężał ten sam „bezpartyjny” komitet wyborców, będący w istocie ekspozyturą lokalnego stowarzyszenia lub grupy nieformalnej. W konsekwencji poprzez wybieranego na kolejne kadencje wójta lub burmistrza od wielu lat

${ }^{21}$ M. Sidor, K.A. Kuć-Czajkowska, Sukcesy wyborcze prezydentów miast, [w:] Demokracja bezpośrednia, red. M. Marczewska-Rytko, S. Michałowski, s. 340-341, 355. 
władzę w gminie sprawuje ta sama organizacja pozarządowa lub lokalna klika, a jeśli nawet następuje zmiana na tym stanowisku, to wewnątrz spetryfikowanej struktury władzy w gminie ${ }^{22}$. Wydaje się, że nie zawsze pełniący w takich warunkach swój urząd włodarz gminy zasługuje na miano lokalnego przywódcy. Nie można przecież wykluczyć sytuacji, gdy dysponujący formalnie tymi wszystkimi zasobami wójt jest w swojej działalności sterowany przez rzeczywistego lidera społeczności lokalnej - osobę spoza oficjalnego układu politycznego, na przykład lokalnego biznesmena czy też miejscowego proboszcza.

Niepokojąca jest wysoka liczba gmin, w których do wyborów na stanowisko wójta lub burmistrza startował jeden kandydat. W 2010 roku gmin takich było 302, w 2014 roku „tylko” 251, a więc około 10\% ogólnej ich liczby. Brak współzawodnictwa politycznego oznacza, że w gruncie rzeczy nie odbywają się wybory, lecz plebiscyt popularności jedynego zarejestrowanego polityka. Pozytywny efekt tego plebiscytu bynajmniej nie jest jednoznaczny z kreowaniem lokalnego przywódcy, gdyż równie dobrze może świadczyć o skutecznym sparaliżowaniu opozycji, likwidacji w gminie politycznego pluralizmu. Jest to alarmujący sygnał zagrożenia demokracji lokalnej.

W samorządzie gminnym po reformie z 2002 roku z dużą siłą wystąpiło zjawisko personalizacji polityki lokalnej oraz stabilizacji składu osobowego, struktury i kanałów wpływu lokalnych elit politycznych. Osoby zajmujące naczelne pozycje w tych elitach mają też coraz bardziej stabilną pozycję w instytucjach samorządowej władzy publicznej. Ich wybór i reelekcja na stanowiska organów wykonawczych gmin mogą, lecz nie muszą być związane z uzyskiwaniem statusu lokalnego przywódcy. Z jednej strony bowiem mandaty niektórych wójtów sprawowane są rzeczywiście przez osoby znane ze sprawności menedżerskiej, posiadające charyzmę i autorytet, skuteczne w działaniach na rzecz rozwoju gminy oraz w zabiegach o pozyskanie środków zewnętrznych (zwłaszcza europejskich) na realizację zadań. Są to osoby, którym opinia publiczna przypisuje, nie zawsze obiektywnie, sukcesy: zmniejszenie bezrobocia, nowe inwestycje, poprawę stanu dróg i infrastruktury.

$\mathrm{Z}$ drugiej strony zdarzają się przypadki zwyciężania w kolejnych wyborach osób dopuszczających się marnotrawstwa środków publicznych, nepotyzmu, korupcji, a nawet kierowania zorganizowaną grupą przestępczą. Niektórzy

22 J. Kurczewski, Lokalne wzory kultury politycznej. Podsumowanie, [w:] Lokalne wzory kultury politycznej, red. idem, Warszawa 2007, s. 573-574. 
z włodarzy gmin są pozbawieni poczucia odpowiedzialności za skutki społeczne swoich działań, za to obdarowani silnym instynktem władzy, pragnieniem narzucania swej woli innym, zdobycia i utrzymania uprzywilejowanej pozycji społecznej, także za pomocą środków niegodnych i niedozwolonych prawem. Ludzie tacy zniechęcają znaczną część społeczności lokalnej do szerszego angażowania się $\mathrm{w}$ sprawy publiczne, co prowadzi do rezygnacji nawet $\mathrm{z}$ czynnego udziału w wyborach samorządowych. Różne wersje idealnego wzoru i antywzoru wójta mają swoje realne odpowiedniki. Między nimi rozciąga się „szara strefa” mniej lub bardziej sprawnych urzędników samorządowych, chyba niepotrzebnie nazywanych lokalnymi przywódcami.

Wśród wójtów jest wielu dobrych administratorów. Są społecznie wiarygodni, to znaczy akceptowani przez społeczności lokalne, jako uczciwi i solidni gospodarze gmin wiejskich lub miast, nieskłonni do potargania krępujących ich więzów prawa w imię własnej kreatywności i pragnienia osobistego sukcesu. Do realizacji takiej roli nie jest jednak potrzebna koncentracja całości faktycznej władzy w gminie w ręku jednego człowieka kosztem eliminacji realnej roli samorządowego przedstawicielstwa oraz za cenę wprowadzenia w to miejsce różnych ułomnych instrumentów partycypacji społecznej.

\section{KONKLUZJE}

Przeważające $\mathrm{w}$ nauce pozytywne opinie o skutkach reformy ustroju gmin z 2002 roku nie znajdują pełnego uzasadnienia w świetle ustalonych faktów społecznych. Niezależność organu wykonawczego doprowadziła do osłabienia instytucji demokracji przedstawicielskiej w gminie, ale bynajmniej nie umocniła demokracji bezpośredniej ani nie spowodowała istotnej zmiany stylu sprawowania urzędu na bardziej prospołeczny. Szczególnie prezydenci dużych miast łatwo stają się uzależnieni od własnego aparatu biurokratycznego oraz grup interesów gospodarczych, które poprzez kanały bezpośredniego dostępu do uczestników procesu podejmowania decyzji zyskują przewagę nad konkurentami i oficjalnymi ośrodkami wpływu społecznego. Podobne reformy nie przyniosły jednoznacznie pozytywnych rezultatów nawet w krajach, w których samorząd jest utrwaloną wartością życia społecznego.

W Polsce nie ma żywych tradycji rozwiązań ustrojowych podporządkowanych idei kreowania burmistrza-lokalnego przywódcy czy też burmistrza-lokalnego menedżera, jak to ma miejsce w miastach USA oraz w tzw. modelu 
południowoniemieckim, rozprzestrzenionym obecnie na całe $\mathrm{Niemcy}^{23}$. Zapożyczenie stamtąd wzoru ustrojowego gminy było zabiegiem ryzykownym, gdyż nieuwzględniającym odmienności polskiej kultury politycznej, a w szczególności naleciałości mentalności klientelistycznej i powiązań typu klikowego u znacznej liczby lokalnych polityków oraz braku nawyków zaangażowania w sprawy publiczne obywateli. W rezultacie pojawiły się niebezpieczne iluzje dotyczące przywódczej roli osób bezpośrednio wybieranych na stanowiska organów wykonawczych gmin przez „większość mniejszości” uprawnionych mieszkańców.

W obecnym stanie prawa wójt, burmistrz lub prezydent miasta łatwo mogą uzyskać de facto hegemoniczną pozycję w systemie władzy w gminie nawet przez kilka kadencji. Nie jest to jednak równoznaczne z rzeczywistym pełnieniem roli przywódcy. Piastuni organów wykonawczych w znacznym stopniu uwolnieni zostali od presji aparatu partyjnego wywieranej za pośrednictwem zdominowanych przez partie rad gmin, ale aparat partyjny dysponuje jeszcze innymi instrumentami uzyskiwania ich pożądanych zachowań, a ponadto łatwo mogą oni stać się zakładnikami własnych współpracowników oraz obiektem presji formalnych i nieformalnych grup nacisku. Mogą też podejmować próby wytworzenia własnego układu powiązań, aby zapewnić sobie ponowny wybór.

Rozwojowi patologicznych powiązań władz lokalnych towarzyszył proces ograniczania, a następnie zaniku ich demokratycznej odpowiedzialności. Referenda odwoławcze od 2003 roku bardzo rzadko przynoszą ważne i skuteczne rozstrzygnięcia, najczęściej są nieudane z powodu zbyt małego udziału mieszkańców. Przez wiele lat quorum wynosiło 30\% uprawnionych do głosowania mieszkańców gminy, co uważano za główną przyczynę niepowodzenia referendum w sprawie odwołania organu gminy. W 2005 roku wprowadzono zmianę - w głosowaniu ma wziąć udział nie mniej niż 3/5 liczby osób biorących udział w ostatnich wyborach odwoływanego organu, aby było ważne. Miało to zwiększyć prawdopodobieństwo rozstrzygającego wyniku referendum. To oczekiwanie w kadencji lat 2006-2010 zostało spełnione w niewielkim stopniu. Nadal w zdecydowanej większości referendów odwoławczych frekwencja była zbyt niska, chociaż wskaźniki skuteczności w porównaniu z poprzednią kadencją nieco się poprawiły (z 12,5\% do 20\%), co w kilku przypadkach „uratowało” ważność procedury odwoławczej - w poprzednim stanie prawnym włodarze ci utrzymaliby swoje stanowiska. Mniejsze niż dotąd szanse powodzenia miała gra

${ }^{23}$ M. Kasiński, Oblicza lokalnego przywództwa we współczesnej Europie, „Samorząd Terytorialny” 2009, nr 9, s. 13-14. 
na zerwanie quorum poprzez wezwanie zwolenników odwoływanego organu do nieuczestniczenia $w$ głosowaniu.

W kadencji 2010-2014 z łącznej liczby 114 referendów dotyczących odwołania wójta ważnych i skutecznych było zaledwie 15 . Liczba referendów w tej sprawie $\mathrm{w}$ porównaniu z poprzednimi kadencjami istotnie wzrosła, ale ich skuteczność spadła ponownie do około $13 \%{ }^{24}$. W wielu przypadkach motywem zarządzenia referendum nie były rzeczywiste wady działania wójta, lecz próba rozwiązania konfliktu między wójtem a radą lub lokalną grupą interesu. Bywało, że formułowane przez inicjatorów zarzuty nie miały rzeczowego charakteru lub były bezpodstawne. Najbardziej niepokojące są jednak przypadki referendów zakończonych pomyślnie dla wójta lub burmistrza, któremu organizatorzy postawili ciężkie i poparte dowodami zarzuty podejmowania niekompetentnych i niegospodarnych decyzji, nepotyzmu, a nawet łamania prawa poprzez praktyki korupcyjne lub zorganizowanie i kierowanie grupą przestępczą. Niepokojący jest również sygnał, że aż w 14 przypadkach w ubiegłej kadencji pozbawienie takich osób mandatu nastąpiło w wyniku utraty prawa wybieralności, co z reguły związane jest $\mathrm{z}$ prawomocnym wyrokiem skazującym. Interpretacje przyczyn stanu niskiej frekwencji w referendach gminnych mogą być różne, nietrafny byłby jednak wniosek, że tylko nieznaczna liczba mieszkańców gmin jest zainteresowana sprawami samorządowymi. Trwała absencja większości z nich w wyborach i referendach jest alarmującym sygnałem, że instytucje demokracji samorządowej przestają być wiarygodne, że słabnie zaufanie społeczne do procedur wyłaniania i oceny piastunów władzy lokalnej. Kryzys koncepcji przypisującej wójtom rolę przywódców lokalnych nie jest jedynie rezultatem niespełnienia nadziei, że bezpośredni wybór na te stanowiska zapewni ich obsadzenie ludźmi o wybitnych walorach moralnych i intelektualnych, o charyzmatycznym wpływie na otoczenie. Jest przede wszystkim związany z coraz bardziej powszechnym odczuciem społecznym, że samorząd lokalny w znacznym stopniu przekształcony został w arenę rozgrywek personalnych w walce o władzę i płaszczyznę realizacji różnych interesów mniejszościowych lub prywatnych.

Obrona rzeczywistych wartości samorządu wymaga działań wielokierunkowych. Zgadzam się z poglądem, że kończy się epoka lokalnych technokratów, menedżerów i przywódców, którzy najlepiej wiedzą, jakie są lokalne problemy i jakimi metodami je rozwiązywać. Mieszkańcom zaś pozostawiają rolę biernego

24 Raport KPRP nt. referendów lokalnych, http://:www.prezydent.pl/kancelaria-działalnosc-kancelarii/art,905, odczyt z dn. 29.11.2014. 
elektoratu, którego jedynym zadaniem jest raz na cztery lata przedłużyć im mandat ${ }^{25}$. Obywatele gmin coraz częściej chcą być partnerami wybranej przez siebie władzy. Stąd płynie potrzeba uzdrowienia przedstawicielstwa, zapewnienia rzeczywistej reprezentatywności rad gmin i wzmocnienia wpływu mieszkańców na sposób realizacji mandatu radnych. Służyłoby temu wprowadzenie zasady wyborów większościowych w okręgach jednomandatowych we wszystkich gminach, także będących miastami na prawach powiatu.

Społecznie uwiarygodnione rady powinny uzyskać znacznie silniejsze uprawnienia kontrolne wobec wójtów, wzmocnione przywróceniem kompetencji do pozbawiania ich stanowisk, choćby tylko z oznaczonych powodów: nieprawidłowego prowadzenia gospodarki finansowej, naruszenia Konstytucji, rażącego naruszenia ustawy na szkodę interesów państwa, wspólnoty samorządowej lub praw obywatelskich. Zmiana taka nie ograniczałaby prawa mieszkańców do odwołania na ich wniosek bezpośrednio wybranego wójta, przeciwnie - umożliwiałaby uproszczenie procedury referendalnej. Wskazane jest też usunięcie rozwiązań tylko pozornie demokratycznych, w szczególności likwidacja pseudowyborów - głosowania nad kandydaturą jedynego zgłoszonego kandydata na stanowisko wójta (burmistrza, prezydenta miasta) oraz rezygnacja z przeprowadzania drugiej tury wyborów, w wyniku której stanowisko zdobywa osoba niedysponująca $\mathrm{w}$ istocie poparciem większości wyborców. W obydwu przypadkach kompetencję wyboru powinna odzyskać rada gminy.

Nade wszystko niezbędne jest ograniczenie dopuszczalności wyboru na stanowisko wójta najwyżej na dwie kadencje. W przeciwnym razie trwać będzie stan, w którym władza efektywna w wielu gminach należy nie do demokratycznie wybranych przedstawicieli, lecz zajmującego pozycję organu wykonawczego lokalnego bossa, kacyka lub mandaryna, zręcznie manipulującego opinią publiczną oraz układami w lokalnej elicie władzy, aby w nieskończoność przedłużać raz zdobyty mandat. Chyba że karierę takiego bossa przerwą ingerencja nadzorcza prezesa Rady Ministrów, interwencja prokuratorska zakończona prawomocnym wyrokiem skazującym lub gwałtowny protest społeczny.

25 D. Sześciło, Reanimacja samorząu, http://www.instytutobywatelski.pl/20449/komentarze, odczyt z dn. 10.02.2015. 